\title{
Cell and Tissue Transplant Strategies for Joint Lesions
}

\author{
I.M. Fuentes-Boquete ${ }^{1,2}$, M.C. Arufe Gonda ${ }^{1,2}$, S.M. Díaz Prado ${ }^{1,2}$, T. Hermida Gómez ${ }^{2}$, \\ F.J. de Toro Santos ${ }^{1,2,4}$, F.J. Blanco ${ }^{2,3,4, *}$
}

${ }^{I}$ Department of Medicine, University of A Coruña, A Coruña, Spain; ${ }^{2}$ CIBER-BBN, Biomedical Research Center, Juan Canalejo Hospital, A Coruña, Spain; ${ }^{3}$ Cathedra BIOIBERICA-University of A Coruña, A Coruña, Spain and ${ }^{4}$ Rheumatology Division. CHU Juan Canalejo. A Coruña, Spain

\begin{abstract}
Articular cartilage lesions that do not disrupt the integrity of subchondral bone are not capable of spontaneous repair. The asymptomatic nature of these lesions leads to articular cartilage degeneration and development of the osteoarthritic process. To avoid joint replacement surgery, several cellular therapies have been developed. These therapies focus on the regeneration of a new tissue, whose structure, biochemistry composition and function should be the same as those of endogenous articular cartilage.

Current approaches for interrupting the osteoarthritic process produce a fibrocartilaginous tissue, not articular cartilage. The implantation of autologous chondrocytes and autologous mosaicplasty induces a better quality of articular cartilage; however, both techniques damage the existing cartilage because of the need to harvest large numbers of chondrocytes or to extract an osteochondral cylinder for implantation. While stem cells are a promising tool for repairing articular cartilage, their use is in an early experimental stage at this time. Although studies of cell therapy have shown clinical and functional improvement in joints, the ability to regenerate articular cartilage that resists the degeneration process remains elusive.
\end{abstract}

Key Words: Articular cartilage, cell therapy, focal cartilage lesions, osteoarthritis, chondrocyte, stem cell.

\section{INTRODUCTION}

Articular cartilage, which is aneural and relatively avascular, receives its nourishment through diffusion from the synovial fluid. The capacity for the self-repair of articular cartilage is limited. Modalities of cellular therapy to repair focal articular cartilage defects include the implantation of cells with chondrogenic capacity and creating access to the bone-marrow. The overall objective is not only to heal the chondral defect (repair), but to generate new tissue identical to native articular cartilage in structure, biochemical composition and functional behaviour (regeneration). This review summarizes the options for treatment of articular cartilage defects from both the experimental and clinical perspective (Fig. 1).

\section{PERFORATION OF THE SUBCHONDRAL BONE}

When the defect affecting the cartilage penetrates to the bone and bone marrow spaces (osteochondral injury), mesenchymal cells from the bone marrow migrate with the hemorrhage and remain in the blood clot filling the defect, and are thus responsible for the repair of the defect (Fig. 2) [1]. Because this repair is limited to the size of the defect, no capacity exists for the spontaneous repair of larger osteochondral injuries. The opening of subchondral vascular

\footnotetext{
*Address correspondence to this author at the Unidad de Investigación del Envejecimiento Osteoarticular, Instituto de Investigacion Biomedica de A Coruña (Inibic), Complejo Hospitalario Universitario Juan Canalejo, C/ Xubias, 84, 15006-A Coruña, Spain; Tel: 34-981-178272; Fax: 34-981178273; E-mail: fblagar@canalejo.org
}

spaces is utilized for several surgical strategies, such as arthroscopic abrasion [2], subchondral drilling [3], spongialization [4] and microfracture (which produces the best results) [5].

Experimental studies in rabbits [6,7] and dogs [8] have shown that the repair tissue generated by these processes is fibrocartilaginous in nature, differing from hyaline articular cartilage in biochemical composition, structural organization, durability and biomechanical properties, and degenerates over time $[1,7]$. The co-expression of types I and II collagens in repair tissue does not occur until one year following subchondral penetration [9]. Clinical results, to some degree, contradict the findings relating to the quality of the repair tissue. For example, the treatment of knee osteochondral defects by microfracture has provided good clinical results after two years [10]. This longevity, however, seems to be age-dependent, with the most persistent repair cartilage in patients under the age of 40 [11]. Although the initiation of a degenerative process for tissue repair has been described at 18 months after microfracture [12], and seven to 17 years after microfracture, improvement in articular function and pain relief were preserved [13].

\section{IMPLANTS OF PERIOSTIUM AND PERICHON- DRIUM}

These membranes contain mesenchymal stem cells that are capable of chondrogenesis $[14,15]$. The periostial or perichondrial implant forms a fibrocartilaginous repair tissue that does not seem to mature over time [16, 17]. However, 



Fibrocartilage
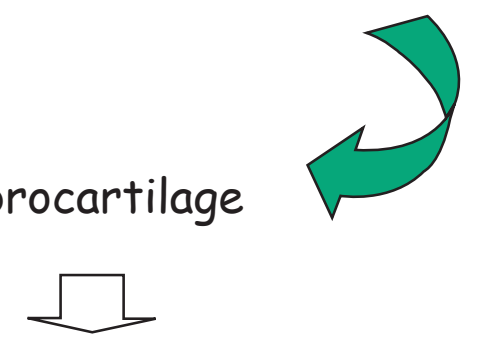

\section{Hyaline Articular Cartilage}

Fig. (1). Different options to treat articular cartilage lesions.

the clinical effects of a perichondrium implant are similar those of subchondral perforation. At 10 years following either procedure there were no significant differences observed between their outcomes [18].

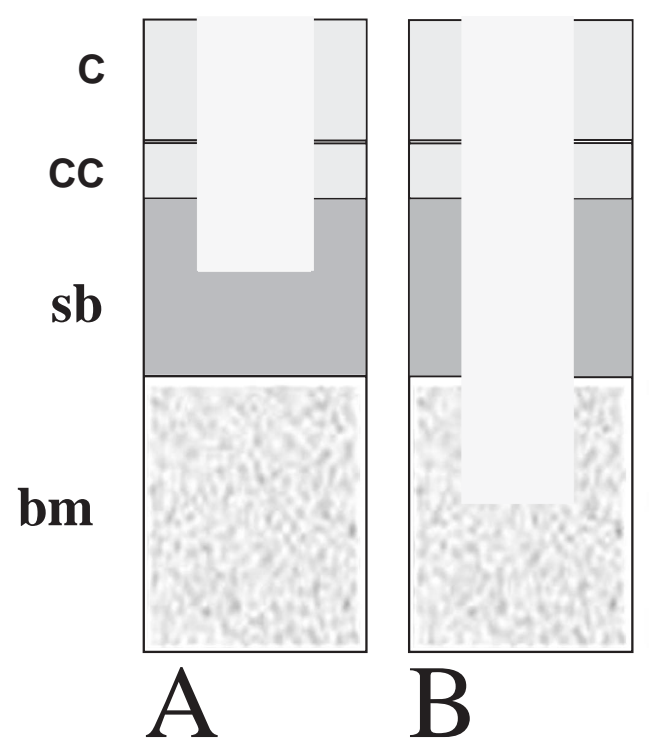

Fig. (2). Types of defects of articular cartilage. A). Partial defect. The lesion includes cartilage tissue and part of the subchondral bone. B). Deep defect. Subchondral bone is perforated to the bone marrow. c: cartilage; cc: calcified cartilage; sb: subchondral bone; bm: bone marrow.

\section{OSTEOPERIOSTEAL IMPLANTS}

Osteoperiosteal plug transplantation (bone plugs with a covering periosteal layer) into a mosaicplasty donor-site defect produces new fibrous tissue in animal models [19] that can acquire fibrocartilaginous characteristics by use of chondrogenic inductors [20]. Bleeding from bone marrow spaces from the injury probably interferes with the repair action of the periostium germ layer. In rabbits, nearly $67 \%$ of repair tissue cells was derived from the bone marrow after osteoperiosteal implantation [21]. Although this repair tissue appears to be of low histological quality, improved articular function and pain relief have been observed following this procedure [22].

\section{MOSAICPLASTY}

Autologous mosaicplasty is considered to be a promising alternative for treatment of small to medium-sized focal chondral and osteochondral defects [23]. This technique involves the translocation of osteochondral cylinders, or plugs, from a low-weight-bearing normal site to a high-weightbearing diseased site. The donor sites spontaneously repair with mesenchymal stromal cells from the bone marrow to promote a new fibrocartilaginous tissue.

Arthroscopic evaluations at five [24] and 10 years [25] after osteochondral cylinder implantation showed survival of the transplanted articular cartilage, congruency between opposing (treated and untreated) joint surfaces and fibrocartilaginous repair of the donor sites. However, if the osteo- 
chondral cylinders protrude above the surface, joint problems can arise. At four months post-surgery, patients with protruding cylinders experienced a "catching sensation" and some of these patients reported joint pain. Arthroscopic examinations of these cases revealed fissures in the osteochondral cylinders and fibrillation around the recipient site [26].

The use of autologous mosaicplasty is limited by the defect size, which determines the number of osteochondral cylinders required. The articular cartilage produced by this technique exhibits topographical variations in morphological, biochemical and physical properties [27, 28]. Because the implanted tissue is harvested from a low-weight-bearing area, the cartilage is thinner and differs in histological structure from cartilage from high weight-bearing areas [29, 30].

\section{OSTEOARTICULAR ALLOTRANSPLANTATION}

The use of osteoarticular allotransplantation may address some of the limitations of mosaicplasty where injury to the low-weight-bearing area of the cartilage is avoided, particularly if a large number of osteochondral cylinders are required. The advantage of the shell allograft is that it is obtained from a donor site that matches the precise location of the recipient and thereby in more likely to have a similar architecture. Furthermore, immunological problems are rare due to the avascular nature of cartilage and the encapsulation of chondrocytes in the extracellular matrix. In practice, shell osteochondral allotransplant in the knee is well integrated and provides a consistent functional improvement and pain relief after two years [31]. Graft requiring larger portions of bone for traumatic defects also do well. After 10 years, $85 \%$ of the implants proved durable [32].

\section{AUTOLOGOUS CHONDROCYTE IMPLANTATION}

A therapeutic alternative offering more effective repair of focal articular cartilage defects is autologous chondrocyte implantation (ACI) [33-36]. This procedure is also used for patients with osteochondritis dissecans [37], but not for osteoarthritis joints. Because the results of this technique are highly age-dependent, the use of this procedure is recommended for patients younger than 55 years of age. The technique involves obtaining, by arthroscopy, articular cartilage explants from low-weight-bearing areas (Fig. 3). Chondrocytes are then isolated and grown in vitro to obtain a sufficient number of cells for implantation. In a second surgical intervention, the cultured chondrocytes are injected into the defect cavity, which is then closed with periosteal membrane from the same patient.

Autologous chondrocyte implantation has several shortcomings: a) obtaining cartilage explants requires an additional surgical intervention, adding to the articular cartilage damage that increases the osteoarthritic process; $b$ ) in vitro chondrocyte proliferation must be limited because the capacity to produce stable cartilage in vivo is gradually reduced when cell divisions are increased [38]; c) aging reduces the cellular density of the cartilage, which impacts chondrocyte proliferation capacity in vitro [39] and the chondrogenic potential of the periostium [40], and $d$ ) cell culture procedures take too long (three to six weeks) and increase the risk of contamination.

The first article about ACI in humans appeared in 1994 [33]. Clinical and arthroscopic evaluations of femoral im- plants showed good results after two years. Early studies demonstrated the durability of the implant, with good clinical results observed at five to 11 years post-procedure [37]. Histological analysis of the de novo formed tissue revealed some heterogeneity in the quality of the repair tissue. Of the 41 biopsies obtained one year following implantation, 10\% consisted of hyaline cartilage; $24 \%$ consisted of a mixture of hyaline cartilage and fibrocartilage; $61 \%$ were entirely fibrocartilage and 5\% consisted only of fibrous tissue [41].

Other studies at one year after implantation have shown that fibrocartilaginous morphology regions and hyaline morphology regions coexist in the same biopsy; both types having proteoglycans and type II collagen $[34,36]$. Furthermore, aggrecanase activity was higher than metalloprotease activities in the fibrocartilaginous regions although both enzymes were found [36]. The expression of type IIA and IIB collagen mRNA was also detected [42]. These mRNA expressions seem be characteristic of the prechondrocytic state (type IIA) and differentiated chondrocytes (type IIB) [43]. These results suggest that ACI induces the regeneration of articular cartilage, probably by the turnover and remodeling from an initial fibrocartilaginous matrix using enzymatic degradation and synthesis of type II collagen [36]. It is believed that this process continues for more than 24 months following the implantation $[35,44]$ and takes place in three specific stages: cell proliferation (the first six weeks), transition (seven to 26 weeks) and remodeling (beyond 27 weeks) [45].

Doubt has been cast upon the use of periosteal membranes for retaining the chondrocyte suspension because the procedure requires a large surgical incision and can lead to peripheral graft hypertrophy and potential ectopic calcification. To obviate this problem, the use of a type I/III collagen patch has been proposed [46-48]. Any differences between the results of using periostium or the collagen patch remain controversial. A comparative study of these two techniques at two years post-operative has revealed no statistically significant differences between the clinical outcomes of ACI with collagen membranes versus ACI with periostium. However, a substantial number of patients who had ACI with periostium required subsequent shaving of an hypertrophied graft [48].

Matrix-associated autologous chondrocyte implantation (MACI) is another procedure that uses a cell-seeded collagen matrix for treatment of cartilage defects. A prospective clinical investigation carried out in 38 patients with localized cartilage defects for a period of up to five years after surgery, showed that MACI represents a viable alternative for treatment of local cartilage defects of the knee [49].

\section{ALLOTRANSPLANTATION AND XENOTRANS- PLANTATION OF CHONDROCYTES}

Other therapeutic alternatives include allotransplantation [50-52] and xenotransplantation of chondrocytes [53, 54]. Allotransplantation is constrained by the necessity for compatible donors and limitations on storage of cartilage or chondrocytes because cryopreservation reduces survival and proliferation of chondrocytes. Xenotransplantation may resolve some of these problems, but this therapeutic alternative has rarely been investigated. The immune barrier is an important objection to the use of both of these procedures. Iso- 

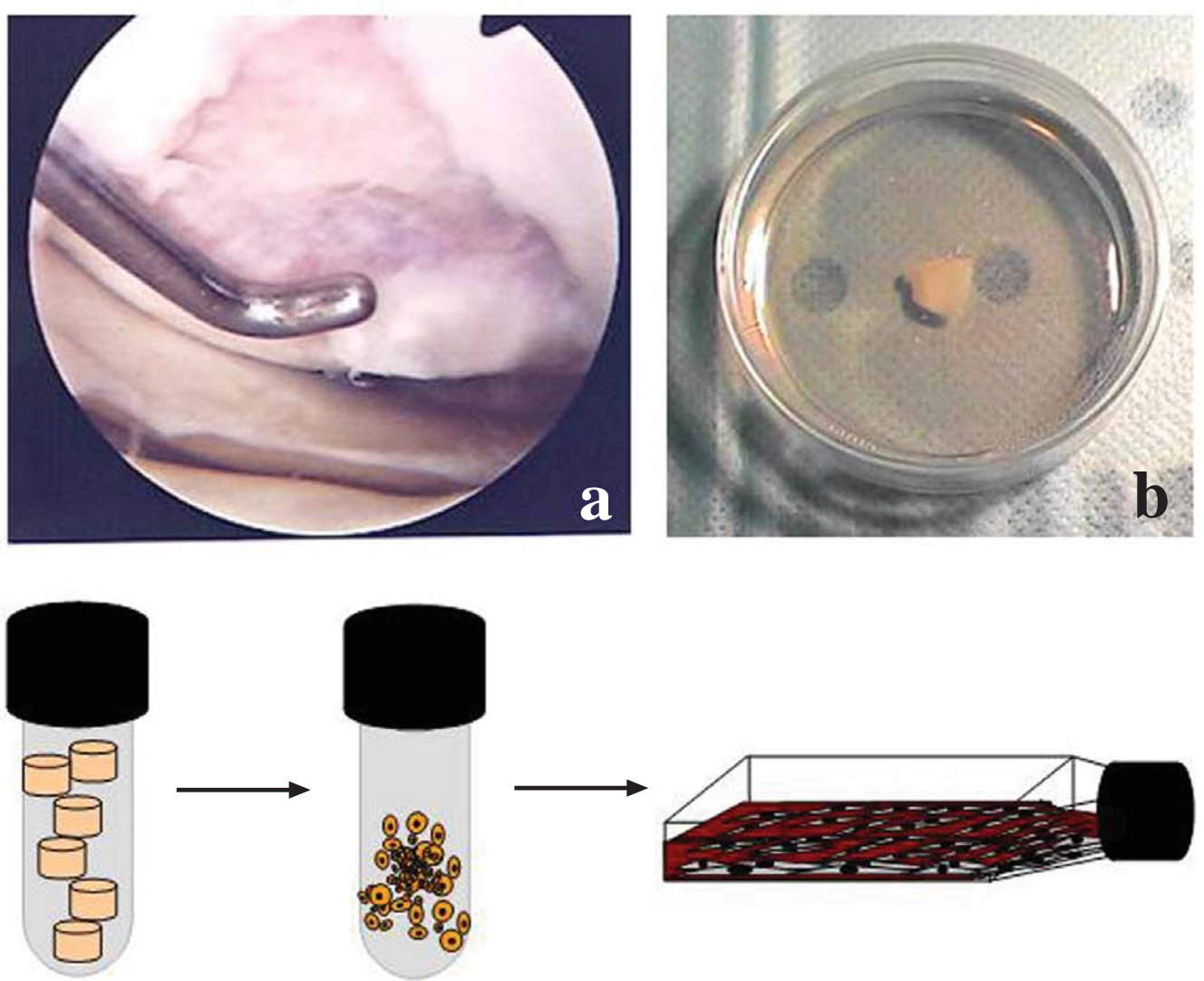

c

d

$\mathbf{e}$
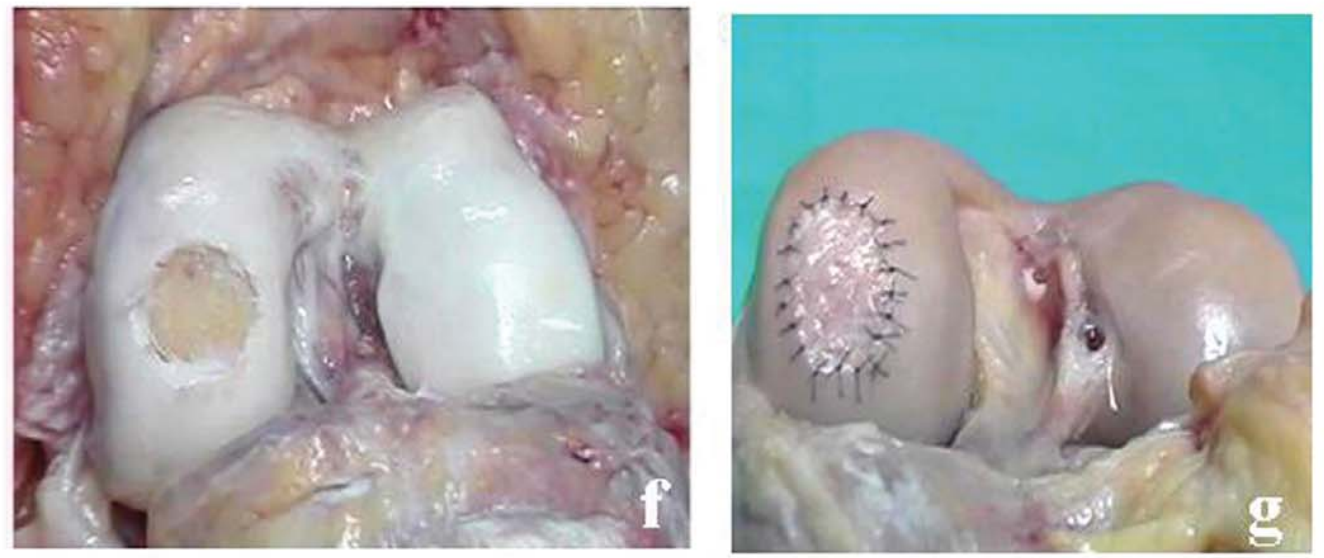

Fig. (3). Implant of autologous chondrocytes. A and B: biopsy. $\mathbf{C}$ and $\mathbf{D}$ : chondrocytes are obtained by by enzymatic digestion (trypsin and type IV collagenase). E: cells proliferate in a culture flask at $37^{\circ} \mathrm{C}$. F: femoral condyle with chondral lesion. G: The defect cavity is closed with a patch (periosteum, type I/III collagen), then the chondrocyte suspension is injected.

lated chondrocytes result in immunogenic reaction, but alloimplantation of chondrocytes encapsulated in their extracellular matrix [52] or embedded in collagen gel or agarose [50, 51] resulted in few or no rejection reactions. Notably, xenotransplantation in vivo of cultured pig chondrocytes into rabbit chondral defects closed with periosteal membrane no signs of infiltration by immune cells [54].

\section{MESENCHYMAL STEM CELLS TRANSPLANTA- TION}

Mesenchymal stem cells (MSCs) can differentiate in vitro into a number of cell types, including adipocytes, chon- drocytes and osteoblasts [55]. This procedure uses cells isolated from small tissue samples, proliferated in culture, to obtain the appropriate number for clinical applications. They can be implanted in the donor patient, obviating rejection problems. Mesenchymal stem cells may be a tool for tissue repair that has the advantage of avoiding the problem of immunological rejection of the allotransplant and the ethical conflict of using embryonic stem cells.

MSCs are wide distributed in vivo, being found in bone marrow [56], periostium [57], perichondrium [58], synovial membrane [59], connective tissue of dermis and skeletal muscle [60], adipose tissue [61], umbilical cord blood [62], 
peripheral blood [63, 64], amniotic membrane [65] and even in articular cartilage [66]. Although bone marrow is the usual source of MSCs, umbilical cord blood is emerging as an important reservoir for stem cells capable of differentiation into many cell types and possessing the advantages of immune status and relatively unshortened telomere length [67].

Because there is no specific marker for MSCs, the principal criteria for identification are adherence to the plastic of the tissue culture flask, fibroblast-like morphology [68], the prolonged capacity for proliferation in supportive media and the capacity to differentiate in vitro into cells of mesodermal origin (chondrocytes, adipocytes, osteoblasts). Furthermore, characteristics of MSCs are the absence of expression of typical hematopoietic antigens like CD34 and CD45, and the expression of surface markers like Stro-1, CD44, CD73, CD90, CD105 y CD166 [69].

The low number of MSCs isolated from a tissue sample requires growth in vitro. However, the number of mitotic divisions of MSCs in culture must be limited because MSCs age during in vitro culture, causing a reduction in their proliferative capacity $[70,71]$ and gradual loss of the potential for multiple differentiation $[70,72]$. The conservation of phenotype and differentiation capacity of MSCs are proportional to telomerization [73]. Telomeres are normally shortened in successive cell divisions, however, in embryonic stem cells the telomere length is restored by telomerase enzyme activity. On the other hand, MSCs lack [74] adequate levels of telomerase activity to achieve telomeric restoration [72, 75, 76]. Patient age also influences the characteristics of MSCs because their proliferative capacity is reduced by aging [77].

Several studies have indicated that the MSC population obtained from a tissue sample contains cell subsets with distinct differentiation stages. Furthermore, MSCs from different tissue sources can have biologic distinctions. For example, MSCs derived from bone marrow show a higher potential for osteogenic differentiation [78], while MSCs of synovial origin show a greater tendency toward chondrogenic differentiation [79]. Under identical culture conditions for differentiation, MSCs isolated from the synovial membrane show more chondrogenic potential than those derived from bone marrow, periostium, skeletal muscle or adipose tissue [80].

Studies of cartilage injury repair in animal models using MSCs embedded in collagen gel [50] or injected into defects closed with periosteal membrane [81] indicate that MSCs can differentiate in vivo into a number of cell types in different biologic environments.

Several studies have recently reported the migration of intraarticularly injected MSCs to the site of a cartilage injury to repair chondral defects. In a caprine model for osteoarthritis in which $\mathrm{OA}$ is induced by the complete excision of the medial meniscus and resection of the anterior cruciate ligament, the intraarticular injection of MSCs produced meniscus repair after six weeks; however, there was no evidence of cartilage or ligament repair [82]. This suggests that the injected MSCs migrated to the injured meniscus, but not the damaged cartilage. The intraarticular injection of MSCs into rat knees, however, showed mobilization of these cells towards all injured tissues, including articular cartilage; the MSCs contributed to tissue regeneration [83, 84].
Studies of treatment with MSCs for human chondral lesions are rare. In osteoarthritic knees, MSCs embedded in collagen gel were implanted into chondral defects and closed with periosteal membrane. After 42 weeks, arthroscopic and histological results were better than in osteoarthritic patients without implants, although there was no statistically significant improvement in clinical results [85]. The use of MSCs to treat chondral lesions clinically has not been established, in part because the stages of chondrogenic differentiation of MSCs are not sufficiently defined. In addition, there are currently no protocols that ensure direct differentiation to the desired phenotype; the plasticity of the cells differentiated from MSCs can lead to undesirable phenotypic alterations $[86,87]$.

\section{SCAFFOLDS}

Scaffold-guided tissue regeneration involves differentiated or mesenchymal stem cells, scaffolds and bio-active factors. Requirements for the biomaterials used as a scaffold include biocompatibility, suitable ligands for implanted cell attachment, integration with native cartilage and biodegradation into non-toxic products that can be replaced by host cells. Other important factors in the design of a scaffold are pore size, porosity, adaptive shape, mechanical integrity, the ability to be retained at the implantation site and cost efficiency.

Natural biomaterials, such as fibrin, collagen, agarose, alginate, hyaluronic acid or chitosan [88-92] and synthetic biomaterials, such as poly-lactic glycolic acid (PLGA) [93] and a polymeric nanofiber [94], are used alone or in different combinations to make scaffolds.

Mechanical and biological properties of biomaterials significantly influence chondrogenesis and the long-term maintenance of the structural integrity of the neo-formed tissue. The three-dimensional nature of the scaffolds promotes maintenance of a rounded cell morphology and the elevated expression of glycosaminoglycans and type II collagen $[92,95]$. However, scaffolding biomaterials have differing influences on the metabolism of host cells and, consequently, the quality of the tissue-engineered cartilage [90, 96]. For example, the use of chitosan, compared to PLGA, for cartilage tissue engineering produces a superior maintenance of structural integrity because the expression of type II collagen protein and mRNA became weaker over time in the PLGA group [96]. Scaffolds using hyaluronic acid are also being used with excellent clinical and histological results [97].

\section{GENE THERAPY}

The introduction of genetic manipulations into the field of tissue damage repair can enhance the process of articular cartilage restoration. This process involves the determination of the appropriate gene and type of cell (chondrocytes, chondrogenic cells and cells of the synovial membrane) for the gene transference, as well as the determination of the optimal vector to incorporate the cDNA [98]. Several anabolic factors [members of the transforming growth factor- $\beta$ (TGF- $\beta$ ) super-family, insulin-like growth factor-1 (IGF-1), fibroblast growth factor (FGF) and hepatocyte growth factor (HGF) induce chondrogenesis and synthesis of extracellular membrane components. Anti-inflammatory molecules, such as 
interleukin-4 (IL-4), IL-10, IL-1 receptor antagonist (IL$1 \mathrm{Ra}$ ), and tumor necrosis factor soluble receptor (TNFsR) act as inhibitors to articular cartilage degradation [99].

The synovial membrane seems useful as a target for chondroprotective therapies [100]. The viral transfection in vivo with the IL-1Ra gene in rheumatoid arthritis joints reduces the severity of the disease process in animal models [101]. Furthermore, this technique makes possible the safe intraarticular expression of the IL-1Ra gene [102, 103]. Chondrocytes and MSCs are the preferred targets for the induction of chondrogenesis. Using animal models, the transplantation in vivo of MSCs transfected with bone morphogenetic protein-2 (BMP-2) cDNA produces improved chondral lesion repair with a higher production of proteoglycans and type II collagen compared to controls [104].

\section{ACKNOWLEDGEMENTS}

The authors thank Ms. P. Cal Purriño for her expert secretarial assistance.

This study was supported by grants from Secretaria I+D+I Xunta Galicia (PGIDIT06PXIC916175PN and from Fondo Investigación Sanitaria (CIBER- CB06/01/0040)Spain. Hermida Gomez T. was supported by a grant from the Fundación Española de Reumatologia (FER).

\section{REFERENCES}

[1] Shapiro F, Koide S, Glimcher MJ. Cell origin and differentiation in the repair of full-thickness defects of articular cartilage. J Bone Joint Surg Am 1993; 75: 532-53.

[2] Friedman MJ, Berasi CC, Fox JM, Del Pizzo W, Snyder SJ, Ferkel RD. Preliminary results with abrasion arthroplasty in the osteoarthritic knee. Clin Orthop Rel Res 1984; 182: 200-5.

[3] Muller B, Kohn D. Indication for and performance of articular cartilage drilling using the Pridie method. Orthopade 1999; 28: 410.

[4] Ficat RP, Ficat C, Gedeon P, Toussaint JB. Spongialization: a new treatment for diseased patellae. Clin Orthop Rel Res 1979; 144: 7483.

[5] Steadman JR, Rodkey WG, Briggs KK, Rodrigo JJ. The microfracture technic in the management of complete cartilage defects in the knee joint. Orthopade 1999; 28: 26-32.

[6] Metsaranta M, Kujala UM, Pelliniemi L, Osterman H, Aho H, Vuorio E. Evidence for insufficient chondrocytic differentiation during repair of full-thickness defects of articular cartilage. Matrix Biol 1996; 15: 39-47.

[7] Menche DS, Frenkel SR, Blair B, et al. A comparison of abrasion burr arthroplasty and subchondral drilling in the treatment of fullthickness cartilage lesions in the rabbit. Arthroscopy 1996; 12(3): 280-6.

[8] Altman RD, Kates J, Chun LE, Dean DD, Eyre D. Preliminary observations of chondral abrasion in a canine model. Ann Rheum Dis 1992; 51(9): 1056-62.

[9] Furukawa T, Eyre DR, Koide S, Glimcher MJ. Biochemical studies on repair cartilage resurfacing experimental defects in the rabbit knee. J Bone Joint Surg Am 1980; 62(1): 79-89.

[10] Knutsen G, Engebretsen L, Ludvigsen TC, et al. Autologous chondrocyte implantation compared with microfracture in the knee. A randomized trial. J Bone Joint Surg Am 2004; 86-A(3): 455-64.

[11] Kreuz PC, Erggelet C, Steinwachs MR, et al. Is microfracture of chondral defects in the knee associated with different results in patients aged 40 years or younger? Arthroscopy 2006; 22(11): 11806.

[12] Kreuz PC, Steinwachs MR, Erggelet C, et al. Results after microfracture of full-thickness chondral defects in different compartments in the knee. Osteoarthritis Cartilage 2006; 14(11): 1119-25.

[13] Steadman JR, Briggs KK, Rodrigo JJ, Kocher MS, Gill TJ, Rodkey WG. Outcomes of microfracture for traumatic chondral defects of the knee: average 11-year follow-up. Arthroscopy 2003; 19(5): $477-84$.
[14] O'Driscoll SW, Saris DB, Ito Y, Fitzimmons JS. The chondrogenic potential of periosteum decreases with age. J Orthop Res 2001; 19: 95-103.

[15] Duynstee ML, Verwoerd-Verhoef HL, Verwoerd CD, Van Osch GJ. The dual role of perichondrium in cartilage wound healing. Plast Reconstr Surg 2002; 110: 1073-9.

[16] Dounchis JS, Bae WC, Chen AC, Sah RL, Coutts RD, Amiel D. Cartilage repair with autogenic perichondrium cell and polylactic acid grafts. Clin Orthop Relat Res 2000; (377): 248-64.

[17] Trzeciak T, Kruczynski J, Jaroszewski J, Lubiatowski P. Evaluation of cartilage reconstruction by means of autologous chondrocyte versus periosteal graft transplantation: an animal study. Transplant Proc 2006; 38(1): 305-11.

[18] Bouwmeester PS, Kuijer R, Homminga GN, Bulstra SK, Geesink RG. A retrospective analysis of two independent prospective cartilage repair studies: autogenous perichondrial grafting versus subchondral drilling 10 years post-surgery. J Orthop Res 2002; 20(2): 267-73.

[19] van Susante JL, Wymenga AB, Buma P. Potential healing benefit of an osteoperiosteal bone plug from the proximal tibia on a mosaicplasty donor-site defect in the knee. An experimental study in the goat. Arch Orthop Trauma Surg 2003; 123(9): 466-70.

[20] Jung M, Gotterbarm T, Gruettgen A, Vilei SB, Breusch S, Richter W. Molecular characterization of spontaneous and growth-factoraugmented chondrogenesis in periosteum-bone tissue transferred into a joint. Histochem Cell Biol 2005; 123(4-5): 447-56.

[21] Zarnett R, Salter RB. Periosteal neochondrogenesis for biologically resurfacing joints: its cellular origin. Can J Surg 1989; 32(3): 1714.

[22] Korkala OL, Kuokkanen HO. Autoarthroplasty of knee cartilage defects by osteoperiosteal grafts. Arch Orthop Trauma Surg 1995; 114(5): 253-6.

[23] Bartha L, Vajda A, Duska Z, Rahmeh H, Hangody L. Autologous osteochondral mosaicplasty grafting. J Orthop Sports Phys Ther 2006; 36(10): 739-50.

[24] Chow JC, Hantes ME, Houle JB, Zalavras CG. Arthroscopic autogenous osteochondral transplantation for treating knee cartilage defects: a 2- to 5-year follow-up study. Arthroscopy 2004; 20(7): 681-90.

[25] Hangody L, Fules P. Autologous osteochondral mosaicplasty for the treatment of full-thickness defects of weight-bearing joints: ten years of experimental and clinical experience. J Bone Joint Surg Am 2003; 85-A(Suppl 2): 25-32.

[26] Nakagawa Y, Suzuki T, Kuroki H, Kobayashi M, Okamoto Y, Nakamura T. The effect of surface incongruity of grafted plugs in osteochondral grafting: a report of five cases. Knee Surg Sports Traumatol Arthrosc 2007; 15(5): 591-6.

[27] Xia Y, Moody JB, Alhadlaq H, Burton-Wurster N, Lust G. Characteristics of topographical heterogeneity of articular cartilage over the joint surface of a humeral head. Osteoarthritis Cartilage 2002; 10(5): 370-80.

[28] Rogers BA, Murphy CL, Cannon SR, Briggs TW. Topographical variation in glycosaminoglycan content in human articular cartilage. J Bone Joint Surg Br 2006; 88(12): 1670-4.

[29] Fragonas E, Mlynárik V, Jellús V, et al. Correlation between biochemical composition and magnetic resonance appearance of articular cartilage. Osteoarthritis Cartilage 1998; 6(1): 24-32.

[30] Gomez S, Toffanin R, Bernstorff S, et al. Collagen fibrils are differently organized in weight-bearing and not-weight-bearing regions of pig articular cartilage. J Exp Zool 2000; 287(5): 346-52.

[31] McCulloch PC, Kang RW, Sobhy MH, Hayden JK, Cole BJ. Prospective evaluation of prolonged fresh osteochondral allograft transplantation of the femoral condyle: minimum 2-year follow-up. Am J Sports Med 2007; 35(3): 411-20.

[32] Gross AE, Shasha N, Aubin P. Long-term followup of the use of fresh osteochondral allografts for posttraumatic knee defects. Clin Orthop Relat Res 2005; 435: 79-87.

[33] Brittberg M, Lindahl A, Nilsson A, Ohlsson C, Isaksson O, Peterson L. Treatment of deep cartilage defects in the knee with autologous chondrocyte transplantation. N Engl J Med 1994; 331: 88995.

[34] Richardson JB, Caterson B, Evans EH, Ashton BA, Roberts S. Repair of human articular cartilage after implantation of autologous chondrocytes. J Bone Joint Surg Br 1999; 81: 1064-8.

[35] Peterson L, Minas T, Brittberg M, Nilsson A, Sjogren-Jansson E, Lindahl A. Two- to 9 year outcome after autologous chondrocyte 
transplantation of the knee. Clin Orthop Rel Res 2000; 374: 21234.

[36] Roberts S, Hollander AP, Caterson B, Menage J, Richardson JB. Matrix turnover in human cartilage repair tissue in autologous chondrocyte implantation. Arthritis Rheum 2001; 44: 2586-98.

[37] Peterson L, Brittberg M, Kiviranta I, Akerlund EL, Lindahl A. Autologous chondrocyte transplantation. Biomechanics and longterm durability. Am J Sports Med 2002; 30(1): 2-12.

[38] Dell'Accio F, De Bari C, Luyten FP. Molecular markers predictive of the capacity of expanded human articular chondrocytes to form stable cartilage in vivo. Arthritis Rheum 2001; 44: 1608-19.

[39] Menche DS, Vangsness CT Jr, Pitman M, Gross AE, Peterson L. The treatment of isolated articular cartilage lesions in the young individual. Instr Course Lect 1998; 47: 505-15.

[40] O'Driscoll SW, Fitzsimmons JS. The role of periosteum in cartilage repair. Clin Orthop Rel Res 2001; 391: S190-207.

[41] Tins BJ, McCall IW, Takahashi T, et al. Autologous chondrocyte implantation in knee joint: MR imaging and histologic features at 1-year follow-up. Radiology 2005; 234(2): 501-8.

[42] Briggs TW, Mahroof S, David LA, Flannelly J, Pringle J, Bayliss M. Histological evaluation of chondral defects after autologous chondrocyte implantation of the knee. J Bone Joint Surg Br 2003; 85(7): 1077-83.

[43] Nah HD, Swoboda B, Birk DE, Kirsch T. Type IIA procollagen: expression in developing chicken limb cartilage and human osteoarthritic articular cartilage. Dev Dyn 2001; 220(4): 307-22.

[44] Bentley G, Biant LC, Carrington RW, et al. A prospective, randomised comparison of autologous chondrocyte implantation versus mosaicplasty for osteochondral defects in the knee. J Bone Joint Surg Br 2003; 85(2): 223-30.

[45] Minas T, Peterson L. Chondrocyte transplantation. Oper Tech Orthop 1997; 7: 323-33

[46] Krishnan SP, Skinner JA, Carrington RW, Flanagan AM, Briggs TW, Bentley G. Collagen-covered autologous chondrocyte implantation for osteochondritis dissecans of the knee: two- to seven-year results. J Bone Joint Surg Br 2006; 88(2): 203-5.

[47] Robertson WB, Fick D, Wood DJ, Linklater JM, Zheng MH, Ackland TR. MRI and clinical evaluation of collagen-covered autologous chondrocyte implantation (CACI) at two years. Knee 2007; 14(2): 117-27.

[48] Gooding CR, Bartlett W, Bentley G, Skinner JA, Carrington R, Flanagan A. A prospective, randomised study comparing two techniques of autologous chondrocyte implantation for osteochondral defects in the knee: Periosteum covered versus type I/III collagen covered. Knee 2006; 13(3): 203-10.

[49] Behrens P, Bitter T, Kurz B, Russlies M. Matrix-associated autologous chondrocyte transplantation/implantation (MACT/MACI)--5year follow-up. Knee 2006; 13: 194-202.

[50] Wakitani S, Kimura T, Hirooka A, et al. Repair of rabbit articular surfaces with allograft chondrocytes embedded in collagen gel. J Bone Joint Surg Br 1989; 71: 74-80.

[51] Rahfoth B, Weisser J, Sternkopf F, Aigner T, von der Mark K, Brauer R. Transplantation of allograft chondrocytes embedded in agarose gel into cartilage defects of rabbits. Osteoarthritis Cartilage 1998; 6: 50-65.

[52] Schreiber RE, Ilten-Kirby BM, Dunkelman NS, et al. Repair of osteochondral defects with allogeneic tissue engineered cartilage implants. Clin Orthop Rel Res 1999; 367S: 382-95.

[53] Fuentes-Boquete I, López-Armada MJ, Maneiro E, et al. Pig chondrocyte xenoimplants for human chondral defect repair: an in vitro model. Wound Repair Regen 2004; 12: 444-52.

[54] Ramallal M, Maneiro E, López E, et al. Xeno-implantation of pig chondrocytes into rabbit to treat localized articular cartilage defects: an animal model. Wound Repair Regen 2004; 12(3): 337-45.

[55] Caplan AI. Mesenchymal stem cells. J Orthop Res 1991; 9: 641-50.

[56] Yoo JU, Barthel TS, Nishimura K, et al. The chondrogenic potential of human bone-marrow-derived mesenchymal progenitor cells. J Bone Joint Surg Am 1998; 80: 1745-57.

[57] Nakahara H, Bruder SP, Haynesworth SE, et al. Bone and cartilage formation in diffusion chambers by subcultured cells derived from the periosteum. Bone 1990; 11: 181-8.

[58] Dounchis JS, Goomer RS, Harwood FL, Khatod M, Coutts RD, Amiel D. Chondrogenic phenotype of perichondrium-derived chondroprogenitor cells is influenced by transforming growth factor-beta 1. J Orthop Res 1997; 15: 803-7.
[59] De Bari C, Dell'Acio F, Tylzanowski P, Luyten FP. Multipotent mesenchymal stem cells from adult human synovial membrane. Arthritis Rheum 2001; 44: 1928-42.

[60] Young HE, Steele TA, Bray RA, et al. Human reserve pluripotent mesenchymal stem cells are present in the connective tissues of skeletal muscle and dermis derived from fetal, adult, and geriatric donors. Anat Rec 2001; 264: 51-62.

[61] Zuk PA, Zhu M, Mizuno H, et al. Multilineage cells from human adipose tissue: implications for cell-based therapies. Tissue Eng 2001; 7: 211-28.

[62] Mareschi K, Biasin E, Piacibello W, Aglietta M, Madon E, Fagioli F. Isolation of human mesenchymal stem cells: bone marrow versus umbilical cord blood. Haematologica 2001; 86: 1099-100.

[63] Kuznetsov SA, Mankani MH, Gronthos S, Satomura K, Bianco P, Robey PG. Circulating skeletal stem cells. J Cell Biol 2001; 153: 1133-40.

[64] Zvaifler NJ, Marinova-Mutafchieva L, Adams G, et al. Mesenchymal precursor cells in the blood of normal individuals. Arthritis Res 2000; 2: 477-88.

[65] Alviano F, Fossati V, Marchionni C, et al. Term amniotic membrane is a high throughput source for multipotent mesenchymal stem cells with ability to differentiate into endothelial cells in vitro. BMC Dev Biol 2007; 7: 11.

[66] Alsalameh S, Amin R, Gemba T, Lotz M. Identification of mesenchymal progenitor cells in normal and osteoarthritic human articular cartilage. Arthritis Rheum 2004; 50(5): 1522-32.

[67] McGuckin CP, Forraz N, Baradez MO, et al. Production of stem cells with embryonic characteristics from human umbilical cord blood. Cell Prolif 2005; 38(4): 245-55.

[68] Prockop DJ. Marrow stromal cells as stem cells for nonhematopoietic tissues. Science 1997; 276: 71-4.

[69] Pittenger MF, Mackay AM, Beck SC, et al. Multilineage potential of adult human mesenchymal stem cells. Science 1999; 284: 143-7.

[70] Banfi A, Muraglia A, Dozin B, Mastrogiacomo M, Cancedda R, Quarto R. Proliferation kinetics and differentiation potential of $e x$ vivo expanded human bone marrow stromal cells: Implications for their use in cell therapy. Exp Hematol 2000; 28: 707-15.

[71] Bonab MM, Alimoghaddam K, Talebian F, Ghaffari SH, Ghavamzadeh A, Nikbin B. Aging of mesenchymal stem cell in vitro. BMC Cell Biol 2006; 7: 14-20.

[72] Izadpanah R, Trygg C, Patel B, et al. Biologic properties of mesenchymal stem cells derived from bone marrow and adipose tissue. $\mathrm{J}$ Cell Biochem 2006; 99(5): 1285-97.

[73] Abdallah BM, Haack-Sorensen M, Burns JS, et al. Maintenance of differentiation potential of human bone marrow mesenchymal stem cells immortalized by human telomerase reverse transcriptase gene despite [corrected] extensive proliferation. Biochem Biophys Res Commun 2005; 326(3): 527-38.

[74] Zimmermann S, Voss M, Kaiser S, Kapp U, Waller CF, Martens UM. Lack of telomerase activity in human mesenchymal stem cells. Leukemia 2003; 17(6): 1146-9.

[75] Parsch D, Fellenberg J, Brummendorf TH, Eschlbeck AM, Richter $\mathrm{W}$. Telomere length and telomerase activity during expansion and differentiation of human mesenchymal stem cells and chondrocytes. J Mol Med 2004; 82(1): 49-55.

[76] Yanada S, Ochi M, Kojima K, Sharman P, Yasunaga Y, Hiyama E. Possibility of selection of chondrogenic progenitor cells by telomere length in FGF-2-expanded mesenchymal stromal cells. Cell Prolif 2006; 39(6): 575-84.

[77] Stenderup K, Justesen J, Clausen C, Kassem M. Aging is associated with decreased maximal life span and accelerated senescence of bone marrow stromal cells. Bone 2003; 33(6): 919-26.

[78] Muraglia A, Cancedda R, Quarto R. Clonal mesenchymal progenitors from human bone marrow differentiate in vitro according to a hierarchical model. J Cell Sci 2000; 113: 1161-6

[79] Djouad F, Bony C, Häupl T, et al. Transcriptional profiles discriminate bone marrow-derived and synovium-derived mesenchymal cells. Arthritis Res Ther 2005; 7: R1304-15.

[80] Sakaguchi Y, Sekiya I, Yagishita K, Muneta T. Comparison of human stem cells derived from various mesenchymal tissues: superiority of synovium as a cell source. Arthritis Rheum 2005; 52: 2521-9.

[81] Im GI, Kim DY, Shin JH, Hyun CW, Cho WH. Repair of cartilage defect in the rabbit with cultured mesenchymal stem cells from bone marrow. J Bone Joint Surg Br 2001; 83: 289-94. 
[82] Murphy JM, Fink DJ, Hunziker EB, Barry FP. Stem cell therapy in a caprine model of osteoarthritis. Arthritis Rheum 2003; 48: 346474.

[83] Nishimori M, Deie M, Kanaya A, Exham H, Adachi N, Ochi M. Repair of chronic osteochondral defects in the rat. A bone marrowstimulating procedure enhanced by cultured allogenic bone marrow mesenchymal stromal cells. J Bone Joint Surg Br 2006; 88(9): 1236-44.

[84] Agung M, Ochi M, Yanada S, et al. Mobilization of bone marrowderived mesenchymal stem cells into the injured tissues after intraarticular injection and their contribution to tissue regeneration. Knee Surg Sports Traumatol Arthrosc 2006; 14(12): 1307-14.

[85] Wakitani S, Imoto K, Yamamoto T, Saito M, Murata N, Yoneda M. Human autologous culture expanded bone marrow mesenchymal cell transplantation for repair of cartilage defects in osteoarthritic knees. Osteoarthritis Cartilage 2002; 10: 199-206.

[86] De Bari C, Dell'Accio F, Luyten FP. Failure of in vitrodifferentiated mesenchymal stem cells from the synovial membrane to form ectopic stable cartilage in vivo. Arthritis Rheum 2004; 50: 142-50.

[87] Pelttari K, Winter A, Steck E, et al. Premature induction of hypertrophy during in vitro chondrogenesis of human mesenchymal stem cells correlates with calcification and vascular invasion after ectopic transplantation in SCID mice. Arthritis Rheum 2006; 54(10): 3254-66.

[88] Eyrich D, Brandl F, Appel B, et al. Long-term stable fibrin gels for cartilage engineering. Biomaterials 2007; 28(1): 55-65.

[89] Cao H, Xu SY. EDC/NHS-crosslinked type II collagen-chondroitin sulfate scaffold: characterization and in vitro evaluation. J Mater Sci Mater Med 2008; 19(2): 567-75.

[90] Mouw JK, Case ND, Guldberg RE, Plaas AH, Levenston ME. Variations in matrix composition and GAG fine structure among scaffolds for cartilage tissue engineering. Osteoarthritis Cartilage 2005; 13(9): 828-36.

[91] Lisignoli G, Cristino S, Piacentini A, et al. Chondrogenic differentiation of murine and human mesenchymal stromal cells in a hyaluronic acid scaffold: differences in gene expression and cell morphology. J Biomed Mater Res A 2006; 77(3): 497-506.

[92] Nettles DL, Elder SH, Gilbert JA. Potential use of chitosan as a cell scaffold material for cartilage tissue engineering. Tissue Eng 2002; 8(6): 1009-16.
[93] Han SH, Kim YH, Park MS, et al. Histological and biomechanical properties of regenerated articular cartilage using chondrogenic bone marrow stromal cells with a PLGA scaffold in vivo. J Biomed Mater Res A 2008; (In press).

[94] Janjanin S, Li WJ, Morgan MT, Shanti RM, Tuan RS. Moldshaped, nanofiber scaffold-based cartilage engineering using human mesenchymal stem cells and bioreactor. J Surg Res 2008; (In press).

[95] Gong Y, Ma Z, Zhou Q, Li J, Gao C, Shen J. Poly(lactic acid) scaffold fabricated by gelatin particle leaching has good biocompatibility for chondrogenesis. J Biomater Sci Polym Ed 2008; 19(2): 207-21.

[96] Jeon YH, Choi JH, Sung JK, Kim TK, Cho BC, Chung HY. Different effects of PLGA and chitosan scaffolds on human cartilage tissue engineering. J Craniofac Surg 2007; 18(6): 1249-58.

[97] Giannini S, Buda R, Vannini F, Di Caprio F, Grigolo B. Arthroscopic autologous chondrocyte implantation in osteochondral lesions of the talus: surgical technique and results. Am J Sports Med 2008; 36(5): 873-80.

[98] Trippel SB, Ghivizzani SC, Nixon AJ. Gene-based approaches for the repair of articular cartilage. Gene Ther 2004; 11: 351-9.

[99] Gelse K, von der Mark K, Schneider H. Cartilage regeneration by gene therapy. Curr Gene Ther 2003; 3: 305-17.

[100] Palmer G, Pascher A, Gouze E, et al. Development of gene-based therapies for cartilage repair. Crit Rev Eukaryot Gene Expr 2002; 12: 259-73.

[101] Gouze E, Pawliuk R, Gouze JN, et al. Lentiviral-mediated gene delivery to synovium: potent intra-articular expression with amplification by inflammation. Mol Ther 2003; 7(4): 460-6.

[102] Evans CH, Robbins PD, Ghivizzani SC, et al. Transfer and intraarticular expression of the IL-1Ra cDNA in human rheumatoid joints. Arthritis Res 2001; 3(Suppl 1): P33.

[103] Evans CH, Robbins PD, Ghivizzani SC, et al. Gene transfer to human joints: progress toward a gene therapy of arthritis. Proc Natl Acad Sci USA 2005; 102(24): 8698-703.

[104] Park J, Gelse K, Frank S, von der Mark K, Aigner T, Schneider H. Transgene-activated mesenchymal cells for articular cartilage repair: a comparison of primary bone marrow-, perichondrium/periosteum- and fat-derived cells. J Gene Med 2006; 8(1): $112-25$. 